\title{
悪性腫瘍による高カルシウム血症モデルマウスに対する エルカトニンの血漿カルシウム低下作用
}

\author{
磯谷 幸宏, 堀 正幸 \\ 旭化成工業 (株) 薬理第 2 研究所* \\ (1994 年 12 月 7 日)
}

\begin{abstract}
要約 : 悪性腫瘍に起因する体液性因子を介した高カルシウム血症（HHM）に及ぼすカルシトニンの作用を 明らかにするために, FA-6 膵癌細胞を皮下に移植した高カルシウム血症ヌードマウスと副甲状腺ホルモン 関連ペプチド (PTHrP) の持続注入による高カルシウム血症マウスを用いて, ウナギカルシトニンの合成 誘導体であるエルカトニンの作用を検討した. その結果, エルカトニンはいずれの高カルシウム血症モデ ルにおいても強い血漿カルシウム低下作用を示した. その作用は投与後 2 時間で最大となり, 投与後 24 時間では消失した. FA-6 担癌マウスでエルカトニン単回投与の用量依存性について検討したところ，1２ 時間後の血漿カルシウム低下作用は投与量の增加に伴い強くなった. 次に, FA-6 担癌マウスでエルカトニ ン連続投与の効果について検討したところ, エルカトニンの血漿カルシウム低下作用は 5 日間連続投与し ても認められた. また, その作用は用いた担癌マウスの血漿カルシウム濃度の上昇に比例して強くなるこ とが示唆された. 以上のことから, エルカトニンはFA-6 担癌マウスのような急激で重度の高カルシウム 血症を発症するモデルにおいても即効性の血漿カルシウム低下作用を示すこと, その作用は血漿カルシウ ム濃度の上昇に依存して強くなること, また HHM の原因物質であると考えられている PTHrP による高 カルシウム血症モデルでも血漿カルシゥム低下作用を示すことが明らかとなった.
\end{abstract}

\section{緒言}

カルシトニンは, 血清カルシウム低下活性を有するぺ プチドとして Hirsch らにより発見された(1).カルシ トニンの血清カルシウム低下作用は, 正常動物において だけでなく副甲状腺ホルモンやビタミン D 投与による 高カルシウム血症動物においても認められており $(2 \sim 4)$, 臨床的にも副甲状腺機能穴進症や悪性腫瘍に起因する体 液性因子を介した高カルシウム血症（Humoral hypercalcemia of malignancy; HHM) などの治療に 有効であることが報告されている(5〜7). しかしなが ら, 実験動物を用いた HHM モデルでの高カルシウム 血症に対する治療効果についての詳細な検討はなされて いなかった，そこで，ウナギカルシトニンの合成アナロ グであるエルカトニンを用い(8), HHM モデルでの血 漿カルシウム濃度に及ぼす作用について検討した。

HHM モデルとしては, 永田らにより樹立されたヒト

${ }^{*} \overline{\mathbf{T}} 410-23$ 静岡県田方郡大仁町三福 632-1
膵癌由来の FA-6 細胞をヌードマウスに移植し高カルシ ウム血症を引き起こさせたものと(9 11), HHM の主 要な原因物質と考えられている副甲状腺ホルモン関連ぺ プチド (parathyroid hormone-related peptide; PTHrP) をマウスに持続注入したものを用いた(12).

\section{実 験 方 法}

\section{1. 使用薬物}

エルカトニン (旭化成工業, 静岡) は, $0.1 \% \mathrm{BSA}$ を含む $0.1 \mathrm{mM}$ 酢酸バッファー（pH6.0）に溶解した. ヒト PTHrP(1-34)（ペプチド研究所, 大阪）は $\varepsilon$-アミ ノカプロン酸飽和溶液（pH 5.0）に溶解して用いた.

2. 高カルシゥム血症モデルの作成

1）担癌マウスを用いた高カルシウム血症モデルの作 成

実験には 6 週令の Balb/c 系雄性ヌードマウス（日本 チャールズリバー, 神奈川）を使用した．FA-6 膵癌細 胞はヌードマウスに継代移植することで維持した(9). すなわち, FA-6 膵癌細胞をヌードマウス背部の左右の 
皮下に移植し 12 20 日間飼育する. その後，心臓より 全採血を行うことでマウスを屠殺した，癌組織を摘出後， $\alpha$-minimum essential medium (GIBCO) 中で $3 \mathrm{~mm}$ 角に細切し，5 個の組織片を別のヌードマウスに移植し た。この際，屠殺した動物の血漿カルシウム濃度を測定 し, 高カルシゥム血症を発症していることを確認した. 悪性腫瘍による高カルシウム血症モデルもまた， $3 \mathrm{~mm}$ 角に細切した癌組織をヌードマウス背部の左右の皮下に 5 個埋め込むことで作成した.

FA-6 膵癌細胞は皮下に移植すると球状に発育するた め, 腫瘍重量の推定には Battelle Columbus Laboratories Protocol を適用した(13)，すなわち，左 右の腫瘍の短径 (a mm) と長径（b $\mathrm{mm}$ )をそれぞれ 計測し，換算腫瘍重量 $(\mathrm{RW} \mathrm{mg})$ を下記の式により算 出し, 両側の RW の和として求めた.

$$
\mathrm{RW}(\mathrm{mg})=\mathrm{a}^{2} \times \mathrm{b} / 2
$$

2) PTHrP 持続注入による高カルシウム血症モデル の作成

実験には 8 週令の ddY 系雄性マウス（日本エスエル シー, 静岡）を使用した。 PTHrP は浸透圧ミニポンプ (model 2001, Alzet) を用いて，マウスの皮下に持続 的に注入した. PTHrP の投与量は $2.5 \mu \mathrm{g}, 5.0 \mu \mathrm{g}, 10.0$ $\mu \mathrm{g} / \mathrm{day} / \mathrm{mouse}$ とした. なお, 正常コントロールとし て, PTHrP の溶解液である $\varepsilon$-アミノカプロン酸飽和溶 液のみを持続注入する群も設定した。

\section{3. エルカトニンの血漿カルシウム濃度に及ぼす作用}

1) FA-6 担癌マウスの高カルシウム血症

エルカトニンの単回静脈内投与の効果について検討す る場合には, FA-6 細胞を移植し 11 日目にヘパリン処 理へマトクリット管を用いて眼窩より採血し, 血漿カル シウム濃度を測定することで高カルシウム血症の発症を 確認した。これ以降は動物を絶食とし, 翌日 $0.25 \mathrm{u}$, $0.5 \mathrm{u}, 1.0 \mathrm{u} / \mathrm{kg}$ のエルカトニンもしくは溶解液を頸静 脈内に投与した，投与直前並びに投与後 $1,2,4,6$ 時 間目に眼窩より採血を行い，投与後 24 時間目に心臟よ り全採血を行い血漿を得た。 なお，高カルシウム血症動 物でのエルカトニンの血漿カルシウム低下作用の強さを 正常動物でのそれと比較するために同週令・同系統のヌー ドマウスでも検討した.

エルカトニンの連日皮下投与の効果について検討する 場合には, 同様にして腫瘍組織移植後 7 日目に高カル シウム血症の発症を確認し, $1.0 \mathrm{u} / \mathrm{kg}$ のエルカトニン あしくは溶解液の皮下投与を開始した．エルカトニンは 5 日間連日投与し，それぞれの投与直前と投与 2 時間後
に眼窩より採血を行った。なお，この場合マウスには飼 料（CE-2，日本クレア，東京）を自由に与えた.

2) PTHrP 持続注入による高カルシウム血症

$2.5 \mu \mathrm{g} /$ day/mouse で PTHrP をマウスの皮下に持続 注入し, 3 日後に眼窩採血を行い高カルシウム血症を発 症していることを確認した。 また, 溶解液を持続注入し た正常マウスでも同様に眼窩採血を行い血漿カルシウム 濃度を測定した。これ以降は動物を絶食とし, 翌日 1.0 $\mathrm{u} / \mathrm{kg}$ のエルカトニンもしくはその溶解液を尾静脈内に 投与した. 投与直前と投与後 $1,2,4,6$ 時間目に眼窩 採血を行い, 投与後 24 時間目に心臟より全採血を行い 血漿を得た.

\section{4. 血漿の生化学的測定}

血漿カルシウム濃度は OCPC 法で測定した（カルシ ウムC-テストワコー, 和光純薬). また, 血漿無機リン 濃度は p-メチルアミノフェノール還元法で測定した (ホスファC-テストワコー, 和光純薬). アルカリホス ファターゼ活性は Kind-King 法で測定した(14).

\section{5. 統計処理}

デー夕は平均值士標準偏差で示した. 全ての統計処理 は対照群の同時間との間で行った。 2 群間の比較には Student's $t$-test を, 多群間の比較には Williams test を適用した。

\section{実 験 結 果}

\section{1. 担癌マウスを用いた高カルシウム血症モデルの作成} FA-6 担癌マウスの換算腫瘍重量, 体重, 血漿カルシ ウム濃度, 血漿無機リン濃度の経時変化を図 1 に示し た. 換算腫瘍重量は移植後 6 日目まで変化を示さなかっ たが，8９ 日目以降より増加し始め, 移植後 14 日目 には 4 日目の約 2 倍にまで増加した（図 $1 \mathrm{~A}$ )。体重は 換算腫瘍重量の増加の推移に一致して低下した（図 1B). また, 血漿カルシウム濃度は換算腫瘍重量の増加の推移 に一致して上昇した（図 $1 \mathrm{C}$ )。すなおち, 移植後 11 日 目には $13.9 \mathrm{mg} / \mathrm{dl}$ と高カルシゥム血症を呈し始め, 14 日目では $30 \mathrm{mg} / \mathrm{dl}$ を越える重度の高カルシウム血症を 呈した。血䪹カルシウム濃度と換算腫瘍重量を比較した ところ, 両者の間に有意な正の相関を認めた $(\mathrm{r}=0.736$, $\mathrm{n}=47, \mathrm{P}<0.001)$. 血漿無機リン濃度は移植後 11 日 目において $4 \mathrm{mg} / \mathrm{dl}$ にまで低下し，以降低值を維持し た (図 1D). 血漿無機リン濃度についても換算腫瘍重 量との間に有意な負の相関を認めた $(r=0.743, n=41$, $\mathrm{P}<0.001)$. 

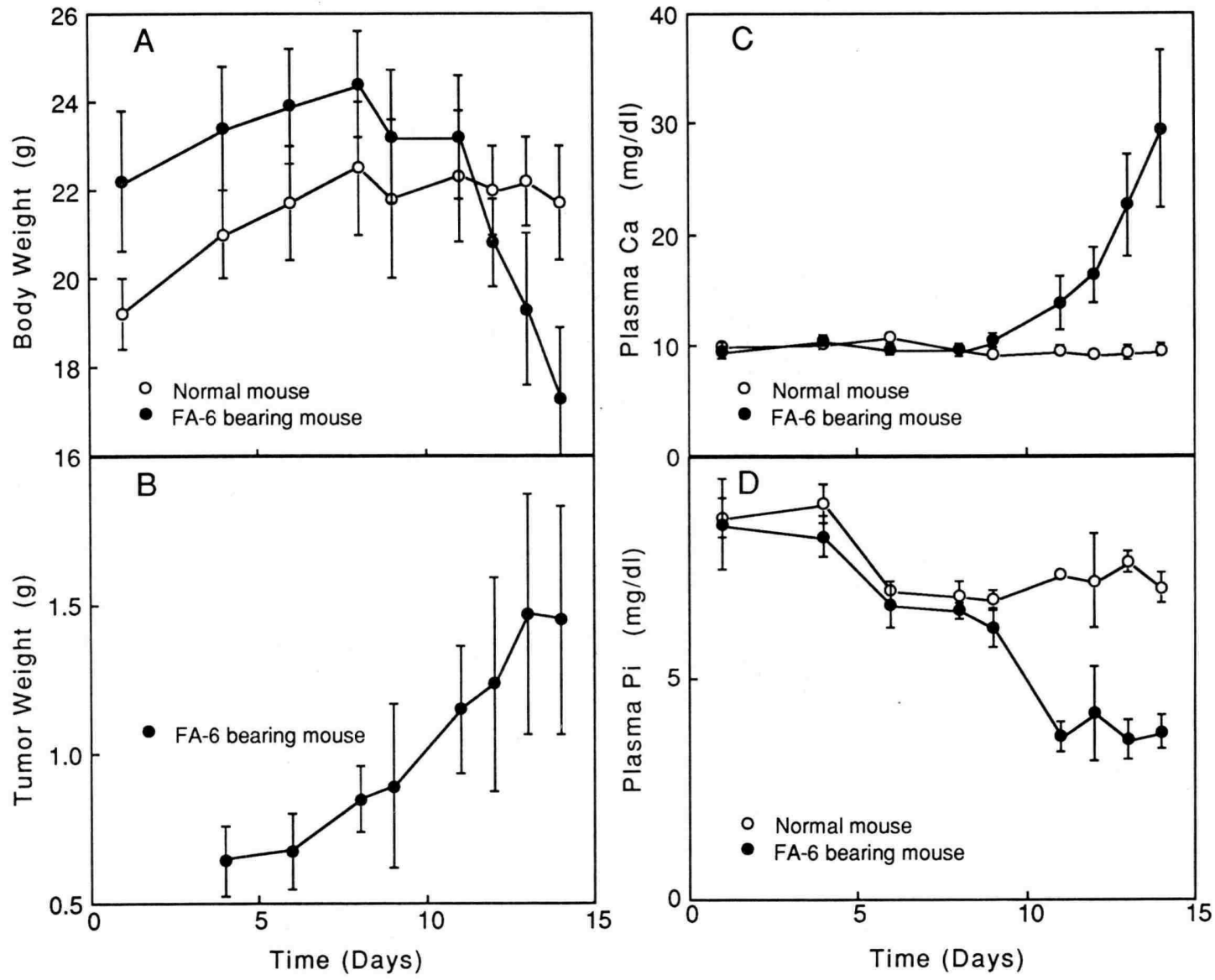

Fig. 1 Establishment of a model for hypercalcemia in FA-6 tumor-bearing mice. Nude mice were transplanted subcutaneously with a pancreas cancer-derived cell line, FA-6. They were examined for changes in body weight (A), tumor weight (B), plasma calcium concentration (C) and plasma inorganic phosphorus concentration (D), as a function of time, designating the day of the tumor transplantation as day 0 . Sham-operated control nude mice were likewise examined. Data were expressed as the mean \pm S.D. of six FA-6 cancer-bearing mice and that of three control mice.

2. 担癌マウスでのエルカトニンの血漿カルシウム濃度 低下作用

FA-6 担癌マウスの高カルシウム血症（血漿カルシウ ム濃度は 14.5〜28.3 mg/dl）および正常マウスの血漿 カルシウム濃度に及ぼすエルカトニン単回静脈内投与の 効果を図 2 に示した. いずれの動物においても, エル カトニンは投与後 2 時間目に最大の血漿カルシウム低 下作用を示した。 また, その作用は 2 時間目以降徐々 に減弱し, 24 時間後には完全に消失した。 エルカトニ ン投与後 2 時間での血漿カルシウム濃度の低下量は用 量依存的であった. 最大低下量は正常マウスで $3 \mathrm{mg} / \mathrm{dl}$
であったのに対し担癌マウスでは $5 \mathrm{mg} / \mathrm{dl}$ であり, 高 カルシウム血症動物での方がより大きかった.

次にエルカトニンの連続投与の効果について検討した (図 3). 移植後 7 日目の FA-6 担癌マウスの血漿カルシ ウム濃度は $10.5 \sim 13.1 \mathrm{mg} / \mathrm{dl}$ であった. エルカトニン を連日皮下投与した群では，溶解液を投与した群に比較 し，血漿カルシウム濃度は投与 1〜5 日目までのいずれ においても有意に低下した。 また，その作用は血漿カル シウム濃度が上昇するにつれて強くなった。 なお，換算 腫瘍重量の増加と体重の減少に対して，エルカトニンは 有意な影響を及ぼさなかった。 


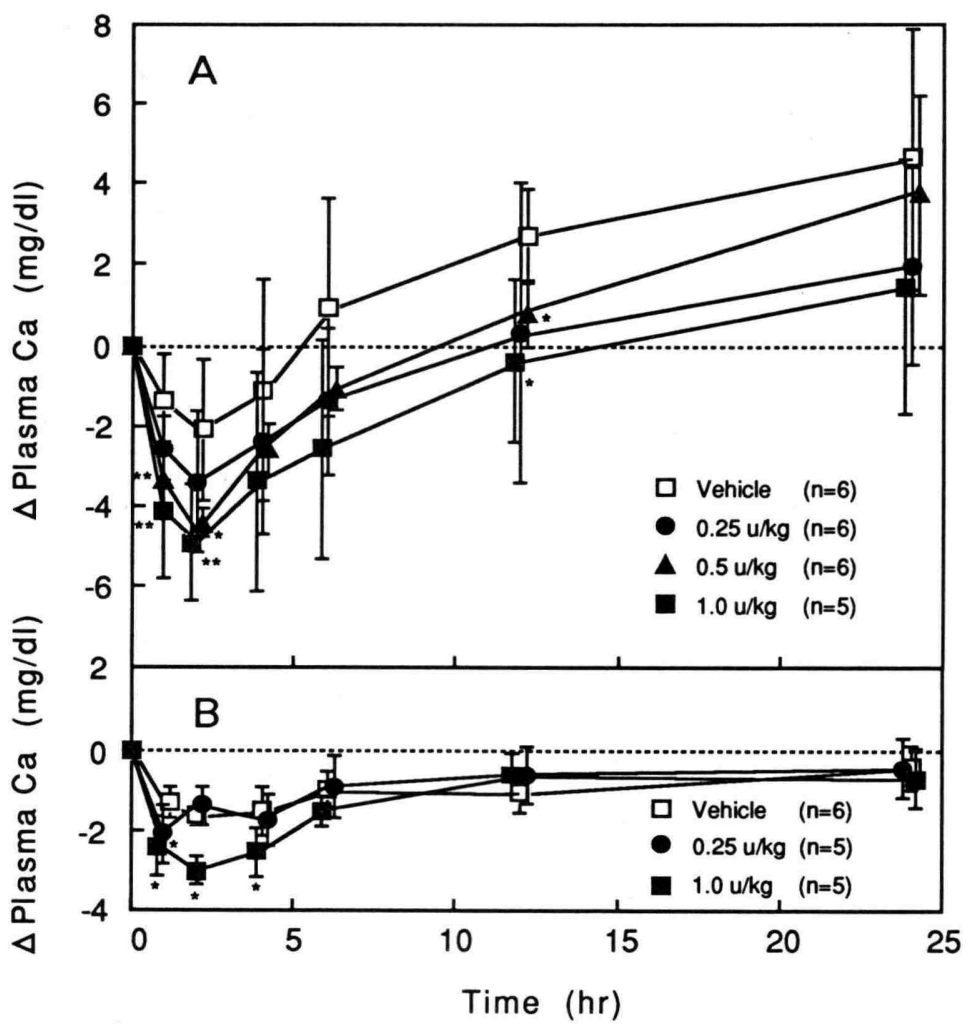

Fig. 2 Effect of single administration of elcatonin on plasma calcium concentrations in FA-6 tumorbearing mice. The FA-6 tumor-bearing mice at day 11 after the transplantation (A) and control normal mice (B) were injected with elcatonin at a dose of $0.25,0.5$, or $1.0 \mathrm{u} / \mathrm{kg}$ or with its vehicle into the carotid vein, respectively. They were then examined for time-dependent changes in plasma calcium concentrations from the pretreatment levels. Data were expressed as the mean \pm S.D. ${ }^{*} \mathrm{P}<0.05,{ }^{*} \mathrm{P}<0.01$, significantly different from the vehicle-treated mice at the same times.

3. マウスへの PTHrP 持続注入による高カルシウム血 症モデルの作成

モデル作成のために PTHrP の投与量に関する検討を 行った (図 4). 血䪹カルシウム濃度は, PTHrPを $5 \mu \mathrm{g} /$ day/mouse 以上投与した群では注入開始後 2 日目にお いて $20 \mathrm{mg} / \mathrm{dl}$ を越えたものの, 3 日目には高カルシウ ム血症の程度が減弱し，5 日目にはほとんどの個体が死 亡した（図 4A）。これに対し，PTHrPを $2.5 \mu \mathrm{g} /$ day/ mouse 投与した群では, 注入開始後 3 日目に $20 \mathrm{mg} / \mathrm{dl}$ に達し，その後 7 日目まで $18 \sim 20 \mathrm{mg} / \mathrm{dl}$ の值を維持 した.

一方血漿無機リン濃度は, PTHrP $5 \mu \mathrm{g} /$ day/ mouse 以上投与した群で, 1 日目に低りン血症を呈し たものの, 2 日目には溶解液投与群と差がなくなった
(図 4B)。これに対し，PTHrPを $2.5 \mu \mathrm{g} /$ day/mouse 投与した群では注入開始後 3 日目に $4 \sim 5 \mathrm{mg} / \mathrm{dl}$ にまで 低下し，以降 7 日目までこの值で推移した.

血漿アルカリホスファターゼ活性は PTHrP $2.5 \mu \mathrm{g} /$ $\mathrm{day} / \mathrm{mouse}$ の 5 日間の投与により, 溶解液投与群で $4.9 \pm 1.4 \mathrm{KAU}$ であったものが, $9.9 \pm 3.5 \mathrm{KAU}$ と有意 に上昇した.

以上の結果から, PTHrP の投与量は 1 日当たり 2.5 $\mu \mathrm{g} /$ mouse とし, エルカトニンの投与は血漿カルシゥム 濃度が安定する 4 日目とした。

4. PTHrP 持続注入マウスでのエルカトニンの血漿カル シゥム濃度低下作用

次に, PTHrP 持続注入マウスの高カルシウム血症に 及ぼすエルカトニンの作用について正常マウスでの作用 


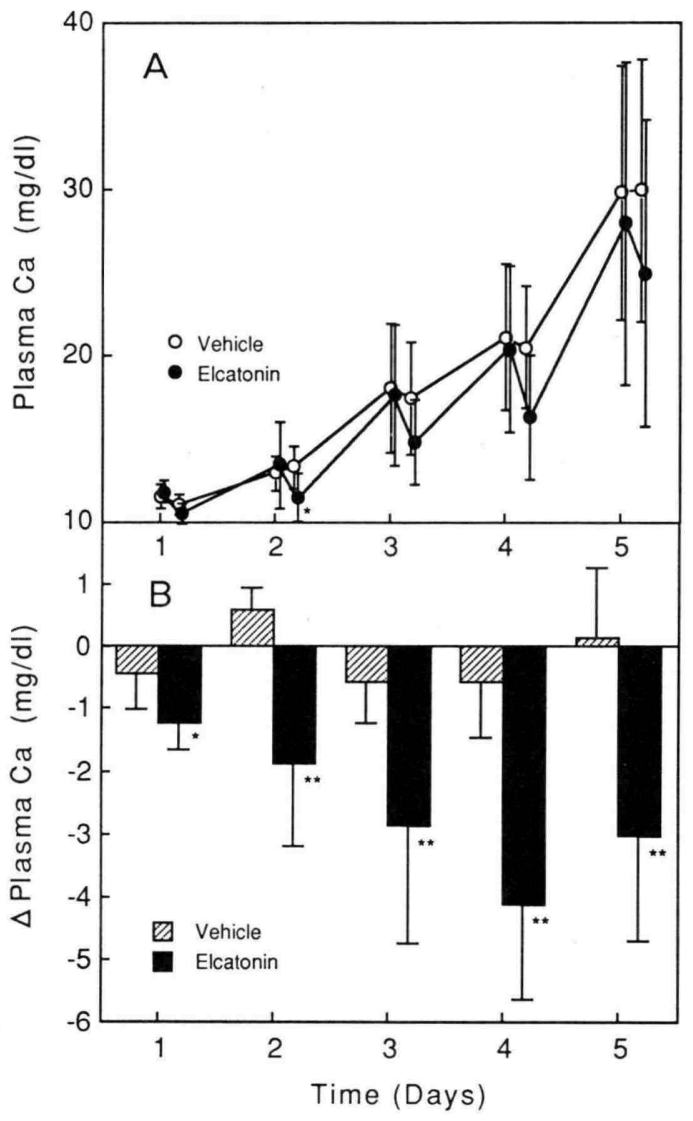

Fig. 3 Effect of daily administration of elcatonin on plasma calcium concentrations in FA-6 tumor-bearing mice. The FA-6 tumor-bearing mice were injected subcutaneously with $1.0 \mathrm{u} / \mathrm{kg}$ of elcatonin or with its vehicle for 5 days from day 7 . The mice were measured for plasma calcium concentrations before and $2 \mathrm{hr}$ after the administration of either agent. The results were shown as the absolute measurements (A) and also as the magnitude of fall in plasma calcium level with the administration of the agents (B). Data were expressed as the mean \pm S.D. of each group of 7 mice. ${ }^{*} \mathrm{P}<0.05,{ }^{* *} \mathrm{P}<0.01$, significantly different from the vehicle-treated mice at the same times.

と比較した（図 5). 血漿カルシウム濃度に対して, PTHrP 持続注入マウスと正常マウスのいずれにおいて あ $1.0 \mathrm{u} / \mathrm{kg}$ のエルカトニンは低下作用を示した (図 5). その作用は 1 時間後より 6 時間目まで持続し 24 時間後 には消失した，また，その作用は正常マウスよりも高力

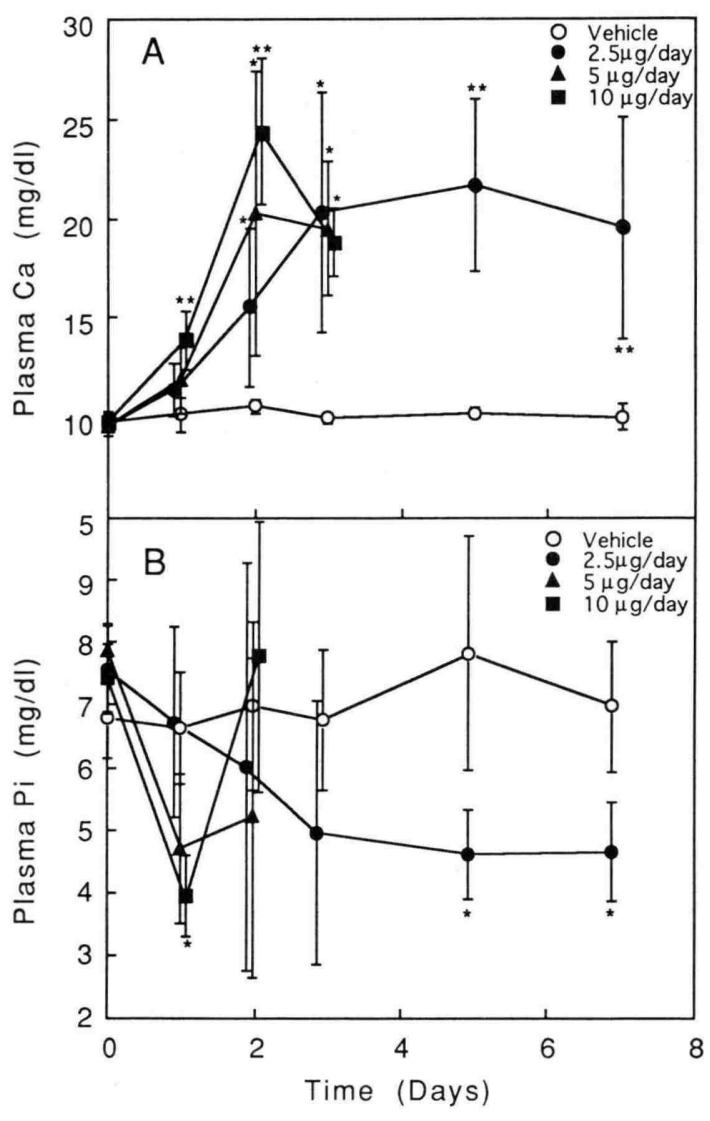

Fig. 4 Establishment of a model for hypercalcemia produced by continuous infusion of PTHrP. Mice were continuously infused subcutaneously with PTHrP at a dose of $2.5,5$ or $10 \mu \mathrm{g} /$ day or with its vehicle by using an osmotic mini-pump; and they were examined for changes in plasma calcium (A) and inorganic phosphorus concentrations (B) with time. Data were shown as the mean \pm S.D. of each group of 4 mice. ${ }^{*} \mathrm{P}<0.05,{ }^{* *} \mathrm{P}<0.01$, significantly different from the vehicle-treated mice at the same times.

ルシウム血症マウスでの方が強かった.

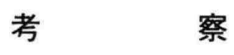

FA-6 細胞は高カルシウム血症の膵癌患者より永田ら により樹立された株化細胞で, ヌードマウスの皮下に移 植すると高カルシウム血症を引き起こすことが報告され ている(9,10). また, FA-6 細胞は PTHrP 様の物質を 産生し, またその培養上清中に TGF $\alpha$ 活性を産生する 


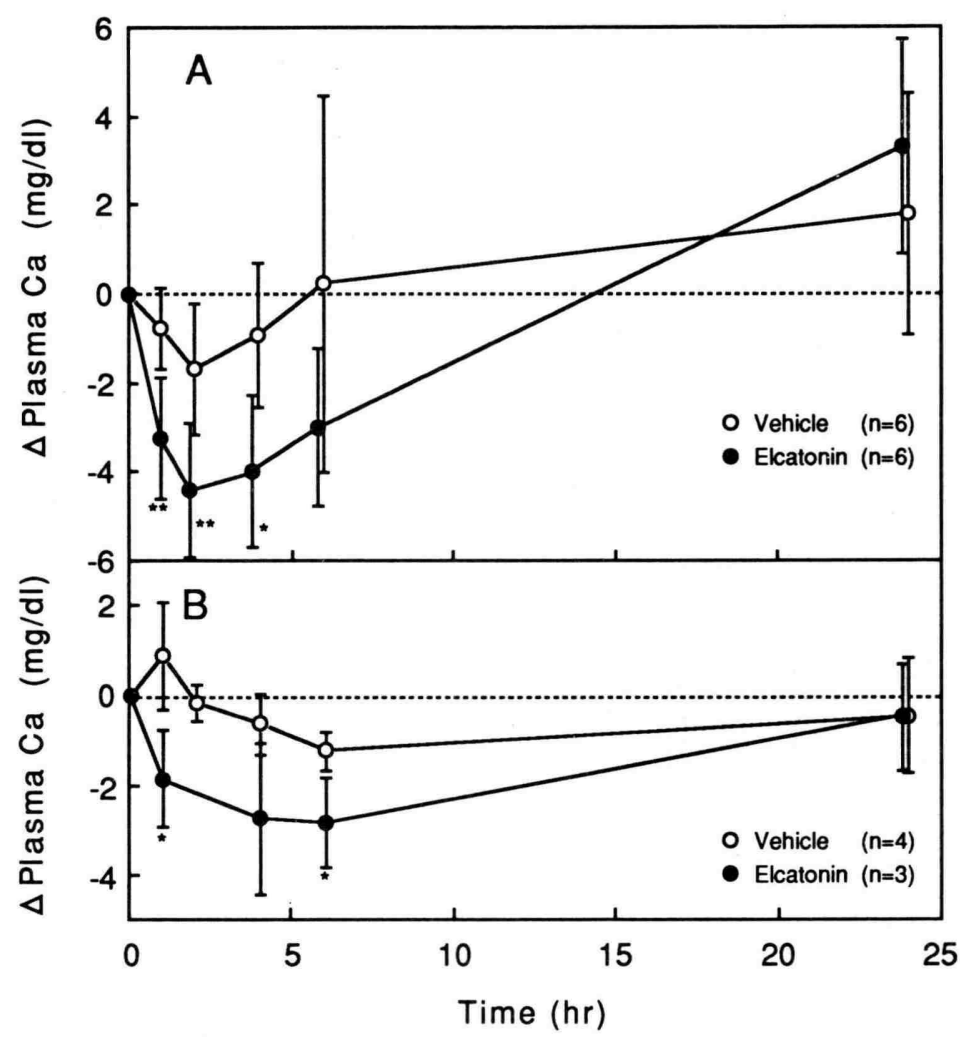

Fig. 5 Effect of single administration of elcatonin on plasma calcium concentrations in mice infused with PTHrP. Mice continuously infused with $2.5 \mu \mathrm{g} /$ day of PTHrP (A) or its vehicle (B) were used. The mice were injected with $1.0 \mathrm{u} / \mathrm{kg}$ of elcatonin or its vehicle into the femoral vein on day 4 after the initiation of PTHrP infusion, and they were examined for time-dependent changes in plasma calcium concentrations from the pretreatment levels. Data were expressed as the mean \pm S.D. ${ }^{*} \mathrm{P}<0.05,{ }^{* *} \mathrm{P}<0.01$, significantly different from the vehicle-treated mice at the same times.

ことからこれらが FA-6 細胞による高カルシウム血症 の原因物質だと考えられている $(9 \sim 11)$. 本研究では, この FA-6 細胞を移植したヌードマウスを HHM モデル として用いるための基礎的検討を行い, その後エルカト ニンの血漿カルシウム濃度に及ぼす作用について検討し た.

基礎検討の結果, FA-6 担癌マウスは癌を移植してか らおよそ 10 日目以降に腫瘍組織の増大に伴い高カルシ ウム血症並びに低リン血症を発症することが明らかとなっ た. また, 高カルシウム血症の発症は, Rice-500 ライ ディッヒ細胞癌を移植したラット，七ト肺胞扁平上皮癌 細胞を移植したマウス, あるいは腹水癌 $\mathrm{S} 180 \mathrm{~A}$ 細胞を 移植したマウスなど, 他の HHM モデル動物に比べ非 常に急速かつ重度であった(15〜18).
FA-6 担癌マウスにおいて, 腫瘍組織は移植 8 9 日 目で増大するにも関わらず, 血漿カルシウム濃度が上昇 するのは 11 日目以降であり時間的に一致していない. 臨床的には副甲状腺機能穴進症やカルシゥムの静脈内注 入による高カルシウム血症発症時に血清中のカルシトニ ンが上昇していることが報告されており, 内因性カルシ トニンの分泌増加を介して血清カルシウム濃度の上昇を 抑制している可能性が示唆されている(19 21). また, Walker carcinoma 256 を移植したラットで血清カルシ ウム濃度が上昇する 1 日前に血清のカルシトニン濃度 が上昇すること, 甲状腺摘除術を施すことで血清カルシ ウム濃度の上昇が 1 日早まることが報告されている(22). これらのことから, FA-6 担癌マウスでも高カルシウム 血症の発症初期には内因性カルシトニンの分泌を介した 
血漿カルシウム濃度の上昇抑制がおこっており，そのた めに腫瘍が大きくなり始めた移植 8 9 日目において血 漿カルシウム濃度の上昇が認められなかったと考えられ る. なお, 高カルシウム血症によって引き起こされる内 因性カルシトニンの上昇は一過性であり, 臨床的にも慢 性的な高カルシウム血症では血中カルシトニンの上昇は 認められていない(22〜24). 従って, FA-6 担癌マウス でも高カルシウム血症の発症後期においては血漿カルシ ウム濃度の調節に内因性カルシトニンは関与していない あのと考えられる.

本モデルにおいて血漿カルシウム濃度に及ぼすエルカ トニンの作用について検討したところ，エルカトニンは 作用時間が短いものの用量依存的な血漿カルシウム低下 作用を示すことが明らかとなった，さらに，この作用の 程度は正常マウスでよりも FA-6 担癌マウスでより強かっ た. その理由として, HHMのような病態では血中の PTHrP 濃度が高くなっており, その濃度に依存して破 骨細胞数の增加と活性化が引き起こされると考えられて いる(25 27). 一方, カルシトニンは破骨細胞に直接 作用し，その骨吸収機能を抑制することで血中へのカル シウムの動員を抑制すると共に, 前破骨細胞から多核の 成熟破骨細胞への分化を抑制することが知られている (28〜30). 従って, HHM のような病態ではエルカト ニンの標的となる破骨細胞が増加しているだけでなく非 常に活性化されているために正常動物に比べてより大き い反応が認められたと考えられる.

カルシトニンを高カルシゥム血症患者に連続的に投与 すると, 初期には強い血漿カルシウム濃度の低下が認め られるものの, 投与回数を重ねるに従い血漿カルシウム 低下作用が減弱してくると報告されている(31). そこ で, FA-6 担癌マウスでのエルカトニンの連続皮下投与 による血漿カルシウム濃度の変化を調べたところ, 作用 の減弱は認められず, むしろ血漿カルシウム濃度の経時 的な上昇に伴ってェルカトニンによる血漿カルシウム低 下量は増加するようになった。このモデルでは血漿カル シウム濃度が日々上昇することから，エルカトニン連続 投与の初期においてはまだ血漿カルシウム濃度が低いた めに作用が弱いのに対し, 後期では血漿カルシウム濃度 が高くなるために強い作用を発揮したと考えられた。 ま た, FA-6 担癌マウスのような急激に高カルシウム血症 を発症するモデルでは，エルカトニン連続投与による作 用の減弱について評価することは困難であると考えられ た.

次に, HHM の主要な原因物質と考えられている
PTHrP の持続投与による高カルシウム血症モデルの作 成を行い, エルカトニンの血漿カルシウム濃度に及ぼす 作用を検討した. Rosol らは 1.0 5.0 $\mu \mathrm{g} /$ day / mouse の PTHrP(1-40) をヌードマウスに持続注入したとこ 万, 用量依存的かつ持続的に血清カルシウム濃度が上昇 し血清無機リン濃度が低下すること, 特に $5.0 \mu \mathrm{g} / \mathrm{day} /$ mouse の注入により安定した血清カルシウム濃度の上 昇が認められることを報告した(12)。私達の結果でも， 注入開始後早期には PTHrP の用量に依存した血漿カル シゥム濃度の上昇と血漿無機リン濃度の低下が認められ た. しかし, 後期には $2.5 \mu \mathrm{g} / \mathrm{day} /$ mouse の PTHrP を 注入した群でのみ持続的な高カルシウム血症と低リン血 症が認められた. $5.0 \mu \mathrm{g} / \mathrm{day} / \mathrm{mouse}$ 以上を投与した群 では 2 日目に作用が減弱あるいは逆転するだけでなく, 3 日目にはほとんどの個体が死亡した. Rosol らの報告 した結果との量的な違いの原因については明らかではな いが, 用いたマウスの系統が違うことや用いた PTHrP の種類が異なることからモル量としては投与量が多いこ となどが考えられる。なお，PTHrP に対する応答性の 質的な違いは認められておらず, PTHrP の持続投与に より血漿のアルカリホスファターゼ活性が上昇し, 下顎 骨の破骨細胞数が増加した (未発表データ). この結果 から，骨のリモデリングは高回転型になっていると考え られた. エルカトニンはこのような PTHrP 持続投与に よる高カルシウム血症モデルにおいても血漿カルシウム 低下作用を示した. また, PTHrP 持続投与による高力 ルシウム血症モデルにおいても正常動物での作用に比較 し, より強い血漿カルシウム值の低下が認められた.

HHM の主要な原因物質はP PHrP であると考えられ ているが, この他にも腫瘍細胞が産生する TGF $\alpha$ や IL1 などのサイトカインの関与も報告されている $(32,33)$. 本研究で用いたFA-6 細胞も PTHrP 以外に TGF $\alpha$ 活 性を産生することが示されており(10), PTHrP 単独で 発症させた高カルシウム血症モデルとは必ずしも同一と はいえない，しかし，TGF $\alpha$ やIL-1 などはいずれも骨 吸収を促進することが知られており，これが一因となっ て高カルシウム血症を発症すると考えられている(34, 35). カルシトニンは破骨細胞の分化と骨吸収機能の両 者とも抑制することが報告されていることから, TGF $\alpha$ や IL-1 に上る骨吸収の元進が原因となる高カルシウム 血症を抑制すると考えられる $(29,30)$. しかし, 高カル シウム血症の発症には腎機能や腸管カルシゥム吸収能も 関与しており，これらに及ぼす TGF $\alpha$ や IL-1 などの作 用が明らかでないことから今後さらに研究が必要であろ 
う.

以上，エルカトニンはいずれの HHM モデルマウス においても短時間で血漿カルシウム低下作用を示した。 また，エルカトニンは血漿カルシウム濃度が高いほど強 い低下作用を示した. 従って, HHM の患者で速急な高 カルシウム血症の改善が必要な場合には, エルカトニン は最も有効な薬剤の一つであると考えられた.

謝辞 : 稿を終えるにあたり, FA-6 膵癌細胞のご供与を 賜りました防衛医大・永田直一教授, および実験に絶大 なる協力をして下さいました佐々木（旧姓佐々）裕美修 士に深謝いたします。

\section{文献}

1) Hirsch PF, Ganthier GF and Munson PL: Thyroid hypocalcemic principle and recurrent laryngeal nerve injury as factors affecting the response to parathyroidectomy in rats. Endocrinology 73, 244-252 (1963)

2) Okada $\mathrm{M}$, Noguchi $\mathrm{S}$, Hasegawa $\mathrm{Y}$ and Inukai $\mathrm{T}$ : Effect of pamidronate in a rat hypercalcemia model induced by cholecalciferol. Arzneimittelforschung 42, 543-546 (1992)

3）墳本敏彦, 堀 正幸, 桜田豊三, 山内広世, 清水 武, 渡辺晋, 早野利夫 : [ $\left.\mathrm{Asu}^{1,}{ }^{1}\right]$-ウナギ・カルチ トニンの薬理作用に関する基礎的研究 (第一報) 各種正常動物における血清カルシウム, イオン化カ ルシウム，および無機リン低下作用について一。現 代の診療 20,1695-1700 (1978)

4）墳本敏彦, 堀 正幸, 桜田豊三, 山内広世, 清水 武, 渡辺晋, 早野利夫 : [Asul, $\left.{ }^{1,7}\right]$-ウナギ・カルチ トニンの薬理作用に関する基礎的研究 (第二報) 実験的高カルシウム血症ラットに対する効果一。現 代の診療 20,1701-1704 (1978)

5）福永仁夫, 土光茂治, 山本逸雄, 森田陸司, 鳥塚 莞爾, 大迫文磨, 井村裕夫, 川村寿一, 吉田 修, 森 徹, 他: 高カルシウム血症患者における合成ウ ナギ・カルチトニンの効果. 臨床と研究 56, 36293636 (1979)

6) Stone MD, Marshall DH, Hosking DJ, GarciaHimmelstine C, White DA and Worth HG: Comparison of low-dose intramuscular and intravenous salcatonin in the treatment of primary hyperparathyroidism. Bone 13, 265-271 (1992)

7) Heath DA: Treatment of hypercalcemia of malignancy. Baillieres Clin Endocrinol Metab 4, 139145 (1990)

8) 小谷 勝, 北沢秀一, 山内広世, 野田俊治, 渡辺 晋：[ $\mathrm{Asu}^{1,7} 7$-ウナギ・カルチトニンの生物活性に ついて. 現代の診療 20, 2217-2222 (1978)

9) Nagata $N$, Kugai N, Maemura M, Akatsu T,
Shimauchi T, Kinoshita T, Kosano H, Takatani O, Tsuda $\mathrm{H}$ and Fuse Y: Enhancement of cyclic adenosine monophosphate content in bone cells by the factor extracted from a pancreatic cancer associated with hypercalcemia. Metabolism 35, 529-534 (1986)

10) Nagata N, Akatsu T, Kugai N, Yasutomo $Y$, Kinoshita T, Kosano H, Shimauchi T, Takatani O and Ueyama Y: The tumor cells (FA-6) established from a pancreatic cancer associated with humoral hypercalcemia of malignancy: A simultaneous production of parathyroid hormone-like activity and transforming growth factor activity. Endocrinol Jpn 36, 75-85 (1989)

11) Miyake $Y$, Yamaguchi $K$, Honda $S$, Nagasaki $K$, Tsuchihashi T, Mori M, Kimura S and Abe K: Production of parathyroid hormone-related protein in tumor xenografts in nude mice presenting with hypercalcemia. Br J Cancer 63, 252-256 (1991)

12) Rosol TJ, Capen CC and Horst RL: Effects of infusion of human parathyroid hormone-related protein-(1-40) in nude mice: Histomorphometric and biochemical investigations. J Bone Miner Res 3, 699-706 (1988)

13）花谷勇次, 久保田哲朗, 山田好則, 露木 建, 中田 宗彦, 熊井浩一郎, 吉野肇一, 石引久弥, 阿部令彦: ヌードマウス可移植性ヒト胃, 結腸癌 5 株を用い た実験的化学療法 - Battelle Columbus Laboratories Protocol の評価を中心に一。 日癌治 療会誌 15, 1114-1120 (1980)

14) Kind PRN and King EJ: Estimation of plasma phosphatase by determination of hydrolysed phenol with amino-antipyrine. J Clin Pathol 7, 322-326 (1954)

15) Insogna KL, Stewart AF, Vignery AMC, Weir EC, Namnum PA, Baron RE, Kirkwood JM, Defttos LM and Broadus AE: Biochemical and histomorphometric characterization of a rat model for humoral hypercalcemia of malignancy. Endocrinology 114, 888-896 (1984)

16) Abramson EC, Kukla LJ, Shevrin DH, Lad TE, McGuire WP and Kukreja SC: A model for malignancy-associated humoral hypercalcemia. Calcif Tissue Int 36, 563-567 (1984)

17) Suzuki K and Yamada S: Ascites sarcoma 180, an animal model of humoral hypercalcemia of malignancy, produces a factor(s) exhibiting potent bone-resorbing activity without any parathyroid hormone-like activity. Bone Miner 14, 1-13 (1991)

18) Ikeda $K$, Matsumoto $T$, Fukumoto $S$, Kurokawa K, Ueyama Y, Fujishige K, Tamaoki N, Saito T, Ohtake $\mathrm{K}$ and Ogata E: A hypercalcemic nude rat model that completely mimics human syndrome 
of humoral hypercalcemia of malignancy. Calcif Tissue Int 43, 97-102 (1988)

19) Parthemore JG and Deftos LJ: Calcitonin secretion in primary hyperparathyroidism. J Clin Endocrinol Metab 49, 223-226 (1979)

20) Heynen G and Franchimont P: Human calcitonin radioimmunoassay in normal and pathological conditions. Eur J Clin Invest 4, 213-222 (1974)

21) Deftos LJ, Weisman MH, Williams GW, Karpf DB, Frumar AM, Davidson BJ, Parthemore JG and Judd HL: Influence of age and sex on plasma calcitonin in human beings. N Engl J Med 302, 1351-1353 (1980)

22) Raue F, Deutschle I, Kuntzel C and Ziegler R: Reversible diminished calcitonin secretion in the rat during chronic hypercalcemia. Endocrinology 115, 2362-2367 (1984)

23) Tiegs RD, Body JJ, Barta JM and Heath III H: Plasma calcitonin in primary hyperparathyroidism: Failure of C-cell response to sustained hypercalcemia. J Clin Endocrinol Metab 63, 785-788 (1986)

24) Lambert PW, Heath III H and Sizemore GW: Preand postoperative studies of plasma calcitonin in primary hyperparathyroidism. J Clin Invest 63 , 602-608 (1979)

25) Kemp BE, Moseley JM, Rodda CP, Ebeling PR, Wettenhall REH, Stapleton D, Diefenbach-Jagger H, Ure F, Michelangeli VP, Simmons HA, et al: Parathyroid hormone-related protein of malignancy: Active synthetic fragments. Science 238, 1568-1570 (1987)

26) Stewart AF, Mangin M, Wu T, Goumas D, Insogna $\mathrm{KL}$, Burtis $\mathrm{WJ}$ and Broadus $\mathrm{AE}$ : Synthetic human parathyroid hormone-like protein stimulates bone resorption and causes hypercalcemia in rats. J Clin Invest 81, 596-600 (1988)

27) Akatsu T, Takahashi N, Udagawa N, Sato K, Nagata N, Moseley JM, Martin TJ and Suda T: Parathyroid hormone (PTH)-related protein is a potent stimulator of osteoclast-like multinucleated cell formation to the same extent as PTH in mouse marrow cultures. Endocrinology 125, 20-27 (1989)

28) Aliapoulios MA, Goldhaber P and Munson PL: Thyrocalcitonin inhibition of bone resorption induced by parathyroid hormone in tissue culture. Science 151, 330-331 (1966)

29) Tamura T, Takahashi N, Akatsu T, Sasaki T, Udagawa $\mathrm{N}$, Tanaka $\mathrm{S}$ and Suda $\mathrm{T}$ : New resorption assay with mouse osteoclast-like multinucleated cells formed in vitro. J Bone Miner Res 8, 953-960 (1993)

30) Takahashi N, Yamana H, Yoshiki S, Roodman GD, Mundy GR, Jones SJ, Boyde A and Suda T: Osteoclast like cell formation and its regulation by osteotropic hormones in mouse bone marrow cultures. Endocrinology 122, 1373-1382 (1988)

31) Binstock ML and Mundy GR: A effect of calcitonin and glucocorticoids in combination on the hypercalcemia of malignancy. Ann Intern Med 93, 269-272 (1980)

32) Mundy GR, Ibbotson KJ and D'Souza SM: Tumor products and the hypercalcemia of malignancy. J Clin Invest 76, 391-394 (1985)

33）赤津拓彦, 高橋直之, 須田立雄 : HHM (Humoral Hypercalcemia of Malignancy) の原因物質, PTH-related protein とその作用. 日本骨代謝誌 6, 63-69 (1988)

34) Ibbotson KJ, Harrod J, Gowen M, D'Souza S, Smith DD, Winkler ME, Derynck R and Mundy GR: Human recombinant transforming growth factor $\alpha$ stimulates bone resorption and inhibits formation in vitro. Proc Natl Acad Sci USA 83, 2228-2232 (1986)

35) Akatsu T, Takahashi N, Udagawa N, Imamura K, Yamaguchi A, Sato T, Nagata N and Suda T: Role of prostaglandins in interleukin-1-induced bone resorption in mice in vitro. J Bone Miner Res 6, 183-190 (1991) 
Abstract-Hypocalcemic effect of elcatonin in mouse models for humoral hypercalcemia of malignancy. Yukihiro ISOGAI and Masayuki HORI (Laboratory for Second Pharmacological Research, Asahi Chemical Industry Co., Ltd., 632-1 Mifuku, Ohito-cho, Tagata-gun, Shizuoka 41023, Japan). Folia Pharmacol. Jpn. 105, 199 208 (1995)

To elucidate the effect of calcitonin on humoral hypercalcemia of malignancy (HHM), we studied the effect of elcatonin, a synthetic eel calcitonin analog, on plasma calcium concentration in hypercalcemic nude mice transplanted subcutaneously with FA-6 pancreas cancer cells and hypercalcemic mice produced by continuous infusion of parathyroid hormone-related peptide (PTHrP). Elcatonin proved to exert a potent hypocalcemic effect in either model for hypercalcemia. The effect reached peaks at $2 \mathrm{hr}$ after its administration, and it was no longer detected at $24 \mathrm{hr}$. The dose-dependent effects of a single administration of elcatonin were studied in the FA-6 tumor-bearing mice: the hypocalcemic effect of elcatonin at 1-2 $\mathrm{hr}$ after administration was dose-relatedly augmented. The effect of daily administration of elcatonin was further studied in the FA-6 tumor-bearing mice: 5-Day daily administration of elcatonin was not accompanied by reduction in its hypocalcemic effect. Moreover, it was suggested that higher the efficacy of elcatonin, the higher were the plasma calcium concentrations in the tumor-bearing mice. These results indicated that elcatonin exerts an immediate hypocalcemic effect even on models for acute and severe hypercalcemia such as FA-6 tumor-bearing mice, that this hypocalcemic effect became more potent depending on their elevation of plasma calcium concentration, and that elcatonin exerts a hypocalcemic effect even on a model for hypercalcemia due to PTHrP, a presumable causative substance of HHM. 